LINGUA, Vol. 16, No. 2, September 2019

p ISSN: 1979 9411; e ISSN: 2442 238X

Http://lingua.soloclcs.org; Email: presslingua@gmail.com

Center of Language and Cultural Studies, Surakarta, Indonesia

Sari, Mustika; Harun, Mohd \& Fitriani, Sarah Siti. 2019. Kemampuan Siswa Kelas V SDN

dalam Gugus 3 Kota Sabang Menulis Kembali Cerita Rakyat uang Dibaca.

Lingua (2019), 16(2): 195-206. Http://doi.org/10.30957/lingua.v16i2.267.

\title{
Kemampuan Siswa Kelas V SDN dalam Gugus 3 Kota Sabang Menulis Kembali Cerita Rakyat yang Dibaca
}

\author{
Mustika Sari $^{1}$, Mohd. Harun ${ }^{2}$ \& Siti Sarah Fitriani ${ }^{3}$ \\ ${ }^{1,2}$ Magister Pendidikan Bahasa Indonesia \\ ${ }^{3}$ Magister Pendidikan Bahasa Inggris \\ Fakultas Keguruan dan Ilmu Pendidikan \\ Universitas Syiah Kuala, Banda Aceh
}

Corresponding e-mail: mohammad harun@unsyiah.ac.id

\begin{abstract}
This study aims at determining the ability of the fifth-grade students of state primary schools (SDNs) located in cluster 3 of Sabang City, Aceh; to rewrite folktales that are read, including the aspects of character, background, plot, language, and punctuation. The approach employed by this study is a descriptive quantitative approach. The population as well as samples in this study were 20 fifth-grade students of SDN 26 and 20 students of SDN 28 Sabang. The research data was collected by test techniques, in the form of assignments. Data is analyzed by quantitative descriptive analysis techniques, namely making a list of raw scores, calculating the average score of students, and classifying the results of the samples studied. The results of the study showed that the ability of the fifth grade students of SDNs in cluster 3 of Sabang City to rewrite the read folklore had not reached the specified value criteria. There are only $35 \%$ of students who have sufficient ability or score above 75 , and many $65 \%$ of students do not have adequate ability who score below 75 . This study also shows that of 40 students, only 3 students get a very good predicate with a score of 90, 30 students obtained a good predicate with a score of 65-85, and 7 students obtained a sufficient predicate with a score of 60 .
\end{abstract}

Keywords: ability, students, rewriting, folktales

\section{PENDAHULUAN}

Keterampilan menulis cerita dapat diamati pada Kurikulum 2013 yang tertuang dalam KI dan KD. Sesuai dengan Kurikulum 2013 yang diterbitkan oleh Kemendikbud (2013), keterampilan menulis terdapat dalam KI-4, yaitu menyajikan pengetahuan faktual dalam bahasa yang jelas, sistematis dan logis, dalam karya yang estetis, dalam gerakan yang mencerminkan anak sehat, dan dalam tindakan yang mencerminkan perilaku anak beriman dan berakhlak mulia. Kemudian, khusus tentang keterampilan menulis cerita terdapat dalam KD 4.4 kelas IV, yaitu menyampaikan teks dongeng tentang kondisi alam dalam bentuk permainan peran secara mandiri dalam bahasa 
LINGUA, Vol. 16, No. 2, September 2019

p ISSN: 1979 9411; e ISSN: 2442 238X

Http://lingua.soloclcs.org; Email: presslingua@gmail.com

Center of Language and Cultural Studies, Surakarta, Indonesia

Sari, Mustika; Harun, Mohd \& Fitriani, Sarah Siti. 2019. Kemampuan Siswa Kelas V SDN

dalam Gugus 3 Kota Sabang Menulis Kembali Cerita Rakyat uang Dibaca.

Lingua (2019), 16(2): 195-206. Http://doi.org/10.30957/lingua.v16i2.267.

Indonesia lisan dan tulis yang dapat diisi dengan kosakata bahasa daerah untuk membantu penyajian. Menyampaikan teks dongeng secara tulisan termasuk dalam latihan atau ptaktik untuk meningkakan kemampuan menulis peserta didik yang dilakukan menggunakan teks cerita fiksi, yang dalam hal ini digunakan teks dongeng.

Dalam pembelajaran bahasa, salah satu cara untuk menilai penguasaan keterampilan menulis adalah dengan menulis kembali sesuatu yang telah diutarakan atau disajikan sebelumnya. Mengenai hal ini, Nurgiyantoro (2004:105) mengatakan bahwa pembelajaran dan pengujian kemampuan apresiasi sastra dilakukan juga melalui kemampuan mendengarkan, membaca, berbicara, dan menulis. Pada penelitian ini, dikaji topik tentang kemampuan menulis siswa menulis kembali cerita takyat yang dibaca. Hal ini juga didukung oleh pendapat Suparno dan Yunus (2009:1) bahwa terdapat kaitan erat antara keterampilan menulis dan membaca. Kalau seseorang menguasai keterampilan membaca, ia pun akan pandai juga dalam menulis. Karena itulah, untuk melihat keterkaitan kedua hal itu, penelitian ini penting dilakukan.

Di samping itu, penelitian tentang kemampuan siswa menulis kembali cerita rakyat pada SDN dalam gugus 3 Kota Sabang belum pernah dilakukan. Pemilihan siswa kelas V SD sebagai objek penelitian karena siswa pada tingkat kelas tersebut adalah siswa tahap pertama yang sudah berada pada penguasaan keempat keterampilan berbahasa. Setakad ini, ditemukan beberapa penelitian mengenai kemampuan siswa menulis kembali. Pertama, Pembelajaran Menulis Kembali Dongeng yang telah Dibaca dengan Metode Konstruktivisme di MTS Al Muttaqin Buper Jayapura oleh Supardi (2016) dan Pembelajaran Menulis Teks Cerita Dongeng Berbasis Kearifan Lokal pada Siswa Kelas $I V$ oleh Heny Kusuma Widyaningrum (2018).

Masalah penelitian ini berfokus pada kemampuan siswa menulis kembali cerita rakyat, meliputi aspek tokoh, latar, alur, bahasa, dan tanda baca. Karena itu, rumusan masalahnya adalah sebagai berikut: bagaimanakah kemampuan siswa kelas V SDN dalam gugus 3 Kota Sabang, Aceh, menulis kembali cerita rakyat yang dibaca, meliputi aspek tokoh, latar, alur, bahasa, dan tanda baca.

\section{LANDASAN TEORI}

\subsection{Menulis Kembali}

Hardjono (1988:86) mengatakan bahwa kemampuan menulis kembali isi bacaan merupakan suatu kegiatan untuk menuliskan pokok-pokok gagasan atau pikiran yang terkandung dalam teks bacaan. Jenis kemampuan menulis ini disebut kemampuan reseptif-reproduktif. Dalam pengembangan kemampuan menulis reseptif-reproduktif ini, teks diberikan kepada siswa. Teks ini merupakan teks tertulis yang dibaca sendiri oleh guru atau siswa atau yang diperdengarkan melalui media audiovisual. Selanjutnya, siswa diinstruksikan untuk menceritakan kembali atau mereproduksi teks tersebut secara keseluruhan atau hanya intinya saja.

Menulis kembali hampir sama halnya seperti menulis rangkuman, ikhtisar, atau sinopsis. Menulis kembali atau merangkum, kedua-keduanya dimulai dengan membaca teks awal. Langkah-langkah menulis kembali suatu dongeng dari hasil bacaan atau dari hasil simakan yang dilakukan menurut Suharma (dalam Widyaningrum, 2018:86) 
LINGUA, Vol. 16, No. 2, September 2019

p ISSN: 1979 9411; e ISSN: 2442 238X

Http://lingua.soloclcs.org; Email: presslingua@gmail.com

Center of Language and Cultural Studies, Surakarta, Indonesia

Sari, Mustika; Harun, Mohd \& Fitriani, Sarah Siti. 2019. Kemampuan Siswa Kelas V SDN

dalam Gugus 3 Kota Sabang Menulis Kembali Cerita Rakyat uang Dibaca.

Lingua (2019), 16(2): 195-206. Http://doi.org/10.30957/lingua.v16i2.267.

adalah (1) mendengarkan atau membaca kembali dongeng yang akan ditulis, (2) memperhatikan bagian demi bagian dongeng dari awal hingga akhir, (3) mengingat kembali alur cerita, pemain atau tokoh, dan unsur-unsur yang lain, (4) membayangkan atau berimajinasi adegan dongeng, seolah-olah pembaca terlibat dalam isi dongeng tersebut, dan (5) menulis kembali isi dongeng dengan menggunakan bahasa Indonesia yang baik dan benar."

\subsection{Cerita Rakyat}

Cerita rakyat adalah cerita yang diciptakan oleh masyarakat dan berkembang di dalam masyarakat. Cerita rakyat juga dikenal dengan sastra fiksi tradisional atau disebut juga sebagai folktale, folklore , atau fairy stories. Sastra tradisional adalah bentuk ekspresi masyarakat pada masa lalu yang umumnya disampaikan secara lisan (Mitchell dalam Nurgiyantoro, 2005:163). Menurut Nurgiyantoro (2005:22), kata "tradisional" menunjukkan bahwa bentuk itu berasal dari cerita yang telah mentradisi, tidak diketahui kapan mulainya, dan siapa penciptanya, dan dikisahkan secara turun-temurun secara lisan. Dengan demikian, dapat dikatakan bahwa cerita rakyat adalah cerita yang dilisankan secara turun-temurun dan bersifat anonim. Dalam hal ini, jenis cerita rakyat mengacu pada pendapat Nurgiyantoro (2005:172) yang dibedakan menjadi fabel, dongeng, mitos, dan legenda.

\subsubsection{Fabel}

Fabel adalah dongeng atau cerita binatang. Cerita fabel adalah sesuatu yang diceritakan dengan tokohnya adalah binatang. Jadi, pada cerita fabel, tokoh binatang ini layaknya tokoh manusia yang dapat berinteraksi dan mempunyai permasalahanpermasalahan layaknya manusia. Cerita dengan tokohnya berupa binatang adalah cerita yang lazim disukai anak. Selain untuk hiburan, dongeng binatang ini sering dijadikan media pembelajaran kepada anak. Bagaimana cara bersikap, bagaimana cara berteman, dan pembelejaran lain sering diselipkan ke dalam fabel.

\subsubsection{Dongeng}

Dongeng (folktale) merupakan cerita prosa rakyat yang termasuk dalam kelompok foklor lisan (Brunvand dalam Harun, 2012:13). Danandjaja (1997:13) juga mengatakan dongeng sebagai cerita pendek kolektif kesusastraan lisan dan termasuk cerita prosa rakyat yang tidak dianggap benar-benar terjadi. Dongeng diceritakan terutama untuk hiburan walaupun banyak juga yang melukiskan kebenaran, berisikan pelajaran (moral), atau bahkan sindiran. Ciri utama dongeng adalah adanya kalimat pembuka dan kalimat penutup yang bersifat klise. Dongeng terbagi dalam empat golongan, yaitu dongeng binatang, dongeng biasa, lelucon dan anekdot dan dongeng berumus. Secara umum dapat dikatakan bahwa dongeng adalah cerita rekaan yang tidak benar-benar terjadi dan banyak berisi hal-hal yang tidak masuk akal. Contoh dongeng dapat diamati juga pada contoh fabel poin 1 sebelumnya karena fabel termasuk dalam kategori dongeng. Namun, umumnya sebutan dongeng dan fabel dibedakan pada tokohnya. Fabel tokohnya berupa binatang dan dongeng tokohnya berupa manusia. 
LINGUA, Vol. 16, No. 2, September 2019

p ISSN: 1979 9411; e ISSN: 2442 238X

Http://lingua.soloclcs.org; Email: presslingua@gmail.com

Center of Language and Cultural Studies, Surakarta, Indonesia

Sari, Mustika; Harun, Mohd \& Fitriani, Sarah Siti. 2019. Kemampuan Siswa Kelas V SDN

dalam Gugus 3 Kota Sabang Menulis Kembali Cerita Rakyat uang Dibaca.

Lingua (2019), 16(2): 195-206. Http://doi.org/10.30957/lingua.v16i2.267.

Selain fabel, cerita dongeng adalah cerita yang lazim didengarkan oleh anak. Oleh karena itu, dongeng biasa ini dipilih sebagai cerita rakyat yang dijadikan bacaan untuk ditulis kembali dalam penelitian ini. Cerita dongeng yang dijadikan sumber bacaan adalah cerita Mentiko Betuah (Ara, 2008). Cerita dongeng tersebut adalah cerita yang telah berkembang secara turun-temurun dalam masyarakat Aceh khususnya dan masyarakat Indonesia secara umum.

\subsubsection{Mitos}

Mitos adalah salah satu jenis cerita lama yang sering dikaitkan dengan dewadewa atau kekuatan-kekuatan supranatural yang lain yang melebihi batas-batas kemampuan manusia. Mitos juga diartikan sebagai cerita prosa rakyat yang dianggap benar-benar terjadi serta dianggap suci oleh pemilik cerita (Bascom dalam Harun, 2012:93). Pada umumnya, mitos mengisahkan tentang terjadinya alam semesta, dunia, manusia pertama, terjadinya maut, bentuk khas binatang, bentuk topografi, gejala alam, dan sebagainya (Harun, 2012:93).

Ada beberapa jenis mitos, yaitu mitos penciptaan, mitos alam, mitos kepahlawanan, dan mitos sejarah. Pertama, mitos penciptaan adalah mitos yang menceritakan dan atau menjelaskan awal mula kejadian sesuatu. Kedua, mitos alam adalah mitos yang menjelaskan hal-hal yang bersifat alamiah. Ketiga, mitos kepahlawanan adalah mitos yang mengisahkan seorang tokoh yang menjadi pahlawan karena kualifikasi dirinya yang memiliki keajaiban tertentu di luar nalar kemanuasiaan. Terakhir, mitos sejarah adalah mitos yang berhubungan dengan peristiwa sejarah, peristiwa dan tokoh yang benar-benar ada dan terjadi.

\subsubsection{Legenda}

Legenda adalah cerita magis yang berkaitan dengan tokoh, peristiwa, dan tempat-tempat yang nyata. Legenda sering diartikan sebagai cerita tentang asal-usul terjadinya suatu tempat yang dianggap benar oleh si pembuat cerita. Selain itu, Harun (2012:118) menyatakan bahwa legenda adalah cerita prosa rakyat yang oleh pemilik cerita dianggap benar-benar pernah terjadi, tetapi tidak dianggap suci.

Ada beberapa jenis legenda, yaitu legenda keagamaan, legenda alam ghaib, legenda perseorangan, legenda tempat, dan legenda peristiwa. Legenda keagamaan adalah legenda yang berhubungan dengan orang-orang saleh. Legenda alam ghaib adalah legenda yang yang berbentuk kisah yang dianggap benar-benar pernah terjadi dan pernah dialami seseorang. Legenda perseorangan adalah legenda mengenai tokohtokoh tertentu yang dianggap benar-benar terjadi. Legenda tempat adalah legenda yang menceritakan tentang suatu tempat, nama tempat, dan bentuk topografi.

\subsubsection{Unsur-Unsur Cerita Rakyat}

Unsur-unsur cerita meliputi tokoh, latar, alur, sudut pandang, gaya bahasa, stile, dan tema. Namun, pada penelitian ini hanya beberapa saja yang menjadi fokus dalam aspek yang dinilai dalam cerita rakyat. Sehubungan dengan itu, aspek penilaian yang dijadikan acuan dalam menilai cerita rakyat yang ditulis kembali oleh siswa meliputi: 
tokoh, latar, alur, serta ditambah dengan kalimat dan tanda baca. Kalimat dan tanda baca dijadikan salah satu aspek yang dinilai karena cerita apa pun yang ditulis bermula dari bahasa, pilihan kata, pembentukan kalimat hingga alinea (Ishak, 2014:127). Seperti yang dinyatakan juga oleh Nurgiyantoro (2004:111) bahwa dalam pembelajaran sastra penilaian hasil kerja siswa yang dilihat meliputi hal ketepatan pengungkapan gagasan yang didukung oleh ketepatan bahasa dan ejaan. Namun, dalam penelitian ini, aspek ejaan hanya difokuskan pada aspek tanda baca.

\section{METODE}

\subsection{Pendekatan dan Jenis Penelitian}

Penelitian ini menggunakan pendekatan kuantitatif berjenis deskriptif. Desain deskriptif kuantitatif adalah rancangan penelitian yang menggambarkan variabel penelitian dalam bentuk angka. Kemudian, angka-angka tersebut menjadi gambaran dari kemampuan siswa kelas V SDN dalam gugus 3 Kota Sabang menulis kembali cerita rakyat yang dibaca, meliputi aspek tokoh, latar, alur, bahasa, dan tanda baca. Angkaangka tersebut diperoleh melalui hasil tes. Variabel yang dimaksud dalam penelitian ini adalah kemampuan siswa menulis kembali cerita rakyat. Dalam penelitian ini, cerita rakyat yang dijadikan sebagai sumber bacaan siswa kelas V SDN dalam gugus 3 Kota Sabang menulis kembali cerita yang dibaca adalah cerita dongeng Mentiko Betuah.

\subsection{Populasi dan Sampel Penelitian}

Populasi penelitian ini adalah siswa kelas V SDN 26 dan SDN 28 Sabang yang berjumlah 40 orang (20 siswa SDN 26 dan 20 siswa SDN 28). Populasi tersebut sekaligus dijadikan sebagai sampel penelitian. Pengambilan sampel merujuk ke pendapat Arikunto (2012:112) bahwa "Jika populasi penelitian kurang dari 100, baik diambil seluruhnya. Akan tetapi, apabila subjeknya lebih dari 100, diambil 10-15\% atau 20-25\% atau lebih". Untuk lebih jelasnya, sampel berupa siswa kelas V SDN 26 dan SDN 28 Sabang dapat diamati pada tabel berikut.

Tabel 1 Jumlah Siswa Kelas V SDN 26 dan SDN 28 Sabang

\begin{tabular}{|c|l|l|l|}
\hline No. & \multicolumn{1}{|c|}{ Sekolah } & \multicolumn{1}{|c|}{ Laki-laki } & Perempuan \\
\hline 1. & SDN 26 & 9 orang & 11 orang \\
\hline 2. & SDN 28 & 7 orang & 13 orang \\
\hline \multicolumn{2}{|c|}{ Jumlah } & \multicolumn{3}{|c|}{ Orang } \\
\hline
\end{tabular}

\subsection{Instrumen Penelitian}

Instrumen penelitian ini adalah tes penugasan. Data yang diperlukan adalah seluruh data yang mendukung pengukuran pengetahuan, keterampilan, serta kemampuan siswa dalam menulis kembali cerita rakyat yang telah dibacanya. Cerita rakyat yang dipilih dalam instrumen ini adalah cerita Mentiko Betuah yang diambil dari buku Cerita Rakyat dari Aceh (Ara, 2008). 


\subsection{Anggapan Dasar}

Anggapan dasar dalam penelitian ini adalah siswa telah mengikuti pelajaran materi menulis kembali cerita rakyat yang dibaca.

\subsection{Hipotesis Penelitian}

Hipotesis dalam penelitian ini adalah siswa mampu menulis kembali cerita yang telah dibaca.

\subsection{Teknik Pengumpulan Data}

Data penelitian ini dikumpulkan dengan teknik tes. Teknik ini digunakan untuk mengetahui kemampuan siswa dalam menulis kembali cerita rakyat yang diberikan. Teknik tes berupa unjuk kerja menulis kembali cerita rakyat yang dilakukan selama 2x35 menit atau selama dua jam pelajaran. Langkah-langkah pengumpulan data adalah (1) peneliti memberikan teks cerita rakyat Mentiko Betuah kepada seluruh siswa yang menjadi subjek penelitian; (2) siswa diberi waktu selama kurang lebih 25 menit untuk membaca dan memahami teks cerita rakyat tersebut; (3) teks yang telah diberikan dikumpulkan kembali; (4) setiap siswa diberi tugas untuk menulis kembali cerita rakyat yang telah dibaca berdasarkan pemahaman mereka masing-masing minimal 150 kata. Setelah itu, lembar kerja siswa diperiksa dan diberikan nilai sesuai dengan teknik analisis data yang digunakan.

\subsection{Teknik Analisis Data}

Teknik analisis data yang digunakan dalam penelitian ini adalah teknik analisis deskriptif kuantitatif. Berikut dipaparkan teknik menganalisis data pada penelitian ini.

1) Membuat Daftar Skor Mentah

Rumus yang digunakan untuk menghitung skor yang diperoleh siswa dalam menyelesaikan soal essai yang diberikan sebagai berikut.

$$
\text { Nilai }=\frac{S}{S M} \times 100
$$

Keterangan:

$\mathrm{S}$ = skor yang diperoleh siswa

$\mathrm{SM}=$ skor maksimal

2) Menghitung rata-rata skor siswa

Rata-rata skor diperoleh menggunakan rumus:

$$
X i=\frac{\Sigma x}{N} x 100
$$

Keterangan:

$\mathrm{Xi}=$ rata-rata skor

$\Sigma \mathrm{x}=$ jumlah keseluruhan $\mathrm{f}(\mathrm{x})$

$\mathrm{N}=$ jumlah keseluruhan sampel 
LINGUA, Vol. 16, No. 2, September 2019

p ISSN: 1979 9411; e ISSN: 2442 238X

Http://lingua.soloclcs.org; Email: presslingua@gmail.com

Center of Language and Cultural Studies, Surakarta, Indonesia

Sari, Mustika; Harun, Mohd \& Fitriani, Sarah Siti. 2019. Kemampuan Siswa Kelas V SDN

dalam Gugus 3 Kota Sabang Menulis Kembali Cerita Rakyat uang Dibaca.

Lingua (2019), 16(2): 195-206. Http://doi.org/10.30957/lingua.v16i2.267.

Dalam hal ini, nilai hasil lembar kerja siswa dimasukkan dalam tabel distribusi frekuensi. Hal ini untuk memudahkan peneliti menentukan frekuensi dan nilai rataratanya. Kemudian, nilai tersebut dikelompokkan dalam bentuk predikat sangat baik, baik, dan cukup yang mengacu pada Peraturan Mendikbud (2014:10-11) tentang penilaian hasil belajar oleh pendidik pada pendidikan dasar dan pendidikan menengah. Tabel penilaiannya sebagai berikut.

Tabel 2 Predikat Penilaian Hasil Belajar Oleh Pendidik Pada Pendidikan Dasar dan Pendidikan Menengah

\begin{tabular}{|c|c|c|c|}
\hline Rentang Angka & Nilai & Huruf & Predikat \\
\hline $3,51-4.00$ & $87,7-100$ & A & Sangat baik \\
\hline $2,51-3,50$ & $62,7-87,5$ & B & Baik \\
\hline $1,51-2,50$ & $37,7-62,5$ & C & Cukup \\
\hline
\end{tabular}

Tabel nilai tersebut dirangkum dari tabel penilaian nilai ketuntasan kompetensi sikap dan nilai ketuntasan pengetahuan dan keterampilan dalam Permendikbud (2014:10-11). Selanjutnya, nilai-nilai tersebut dimasukkan dalam tabel klasifikasi tingkat kemampuan siswa untuk melihat hasil yang diperoleh tentang mampu atau tidaknya siswa menulis kembali cerita rakyat yang dibaca.

Tabel 3 Klasifikasi Tingkat Kemampuan Siswa Kelas V SDN 26 dan SDN 28 Sabang

\begin{tabular}{|l|l|l|l|}
\hline No. & \multicolumn{1}{|c|}{ Perolehan Nilai } & Frekuensi & Persentase \\
\hline 1. & Nilai 75 ke atas & & \\
\hline 2. & Di bawah 75 & & \\
\hline
\end{tabular}

(Sumber: (Sumber: Modifikasi Nurgiyantoro, 2010)

3) Sampel dikatakan mampu menulis kembali cerita rakyat apabila $80 \%$ siswa mendapat nilai 75 ke atas, sedangkan dikatakan belum mampu jika kurang $80 \%$ siswa mendapat nilai 75 ke bawah.

\section{HASIL}

Menulis kembali cerita rakyat yang dibaca adalah kegiatan menuliskan pokokpokok gagasan atau pikiran yang terkandung dalam teks bacaan. Hasil kegiatan menulis kembali cerita berbeda setiap siswa sehingga menghasilkan nilai yang berbeda. Secara keseluruhan, hasil skor nilai mentah siswa kelas V SDN 26 Sabang dan SDN 28 Sabang sangat variatif.

Hasil penelitian menunjukkan bahwa persentase dan frekuensi nilai kemampuan siswa kelas V SDN 26 adalah siswa yang mendapatkan nilai 75 ke atas sebanyak 8 orang dengan persentase $40 \%$ dan siswa yang mendapatkan nilai di bawah 75 sebanyak 12 orang dengan persentase $60 \%$. Dengan demikian, dapat disimpulkan bahwa kemampuan siswa kelas V SDN 26 sabang menulis kembali cerita rakyat yang dibaca belum memadai karena jumlah siswa yang memperoleh nilai di bawah 75 lebih banyak dibandingkan jumlah siswa yang mendapatkan nilai 75 ke atas. Lebih jelasnya dapat diamati pada tabel berikut. 
LINGUA, Vol. 16, No. 2, September 2019

p ISSN: 1979 9411; e ISSN: 2442 238X

Http://lingua.soloclcs.org; Email: presslingua@gmail.com

Center of Language and Cultural Studies, Surakarta, Indonesia

Sari, Mustika; Harun, Mohd \& Fitriani, Sarah Siti. 2019. Kemampuan Siswa Kelas V SDN

dalam Gugus 3 Kota Sabang Menulis Kembali Cerita Rakyat uang Dibaca.

Lingua (2019), 16(2): 195-206. Http://doi.org/10.30957/lingua.v16i2.267.

Tabel 4 Klasifikasi Tingkat Kemampuan Siswa Kelas V SDN 26 Sabang Menulis Kembali Cerita Rakyat yang Dibaca

\begin{tabular}{|l|c|c|c|}
\hline No. & Perolehan Nilai & Frek. & \% \\
\hline 1 & Nilai 75 ke atas & 8 & 40 \\
\hline 2 & Di bawah 75 & 12 & 60 \\
\hline \multicolumn{2}{|c|}{ Jumlah } & 20 & 100 \\
\hline
\end{tabular}

Begitu pula dengan hasil penelitian pada siswa di SDN 28 Sabang yang menunjukkan bahwa jumlah siswa yang memperoleh nilai 75 ke atas sebanyak 6 orang atau sebesar 30\% dan jumlah siswa yang memperoleh nilai di bawah 75 sebanyak 14 orang siswa atau sebesar $70 \%$ dari 20 siswa. Dengan demikian, dapat disimpulkan bahwa kemampuan siswa kelas V SDN 28 Sabang menulis kembali cerita rakyat yang dibaca belum memadai karena persentase siswa yang mempunyai nilai di bawah 75 lebih besar daripada persentase siswa yang mempunyai nilai 75 ke atas. Hasil ini sama dengan kemampuan siswa kelas V SDN Sabang yang juga belum memadai. Hasilnya dapat diamati pada tabel berikut.

Tabel 5 Klasifikasi Tingkat Kemampuan Siswa Kelas V SDN 28 Sabang Menulis Kembali Cerita Rakyat yang Dibaca

\begin{tabular}{|l|l|c|c|}
\hline No. & Perolehan Nilai & Frekuensi & Persentase \\
\hline 1 & Nilai 75 ke atas & 6 & 30 \\
\hline 2 & Di bawah 75 & 14 & 70 \\
\hline \multicolumn{2}{|c|}{ Jumlah } & 20 & 100 \\
\hline
\end{tabular}

Dari hasil penelitian, secara keseluruhan dapat disimpulkan bahwa siswa kelas $\mathrm{V}$ SDN dalam gugus 3 Kota Sabang dengan sampel penelitian di SDN 26 dan SDN 28 Sabang belum mencapai kriteria atau belum mempunyai kemampuan yang memadai dalam menulis cerita rakyat yang dibaca. Untuk lebih jelasnya, hasil penelitian dua sekolah dapat dikomprehensifkan dalam tabel berikut.

Tabel 6 Klasifikasi Nilai Kemampuan Siswa Kelas V SDN 26 dan SDN 28 Sabang Menulis Kembali Cerita Rakyat yang Dibaca

\begin{tabular}{|c|c|c|c|c|}
\hline No. & Rentang Nilai & Jumlah & Tingkatan Nilai & \% \\
\hline 1 & 90 & 3 & sangat baik & 7,5 \\
\hline 2 & $65-85$ & 30 & Baik & 75 \\
\hline 3 & 60 & 7 & Cukup & 17,5 \\
\hline Jumlah & 40 & 40 & & 100 \\
\hline
\end{tabular}

Terakhir, hasil kemampuan siswa kelas V SDN 26 dan SDN 28 Sabang dapat diamati pada tabel berikut. 
LINGUA, Vol. 16, No. 2, September 2019

p ISSN: 1979 9411; e ISSN: 2442 238X

Http://lingua.soloclcs.org; Email: presslingua@gmail.com

Center of Language and Cultural Studies, Surakarta, Indonesia

Sari, Mustika; Harun, Mohd \& Fitriani, Sarah Siti. 2019. Kemampuan Siswa Kelas V SDN

dalam Gugus 3 Kota Sabang Menulis Kembali Cerita Rakyat uang Dibaca.

Lingua (2019), 16(2): 195-206. Http://doi.org/10.30957/lingua.v16i2.267.

Tabel 7 Rangkuman Hasil Penelitian Klasifikasi Tingkat Kemampuan Siswa Kelas V SDN 26 dan SDN 28 Sabang

\begin{tabular}{|c|l|c|l|}
\hline No. & Perolehan Nilai & Frek & \% \\
\hline 1 & Nilai 75 ke atas & 14 & $\mathbf{3 5}$ \\
\hline 2 & Di bawah 75 & 26 & $\mathbf{6 5}$ \\
\hline \multicolumn{2}{|c|}{ Jumlah } & 40 & $\mathbf{1 0 0}$ \\
\hline
\end{tabular}

\section{PEMBAHASAN}

Berdasarkan hasil analisis data diketahui bahwa kemampuan siswa kelas V SDN 26 dan SDN 28 Sabang belum memadai. Skor yang diperoleh oleh siswa di kedua sekolah tersebut hampir sama, yaitu rentang nilai 60 sampai dengan 90 sehingga nilai terendah dan tertinggi yang diperoleh siswa pun sama. Dari data nilai yang diperoleh, tampak bahwa siswa kelas V SDN 26 mempunyai skor rendah pada alur, begitu pula dengan siswa SDN 28. Hal ini dapat dilihat pada skor penilaian tokoh, latar, alur, bahasa, dan tanda baca yang dijumlahkan. Setelah skor tersebut dijumlahkan, skor alur yang diperoleh siswa berdasarkan unsur yang dinilai memperoleh jumlah terendah, yaitu 270 untuk siswa kelas V SDN 26 dan 260 untuk siswa kelas V SDN 28. Dari data, pada skor alur, 8 orang siswa kelas V SDN 26 memperoleh nilai 10 yang artinya 8 orang menulis kembali cerita rakyat dengan pengungkapan alur yang tidak sesuai dengan cerita yang dibaca. Selain alur, skor latar juga jumlahnya tidak berbeda jauh, yaitu 275. Artinya ada 7 orang yang menulis kembali cerita dengan pengungkapan latar yang tidak sesuai.

Kemampuan yang belum memadai ini terutama dalam penulisan alur sebagai penguasaan terendah. Kemampuan yang memadai yang dilihat dari jumlah siswa yang memiliki penilaian sesuai adalah penguasaan pada unsur tokoh, bahasa, dan tanda baca dengan penguasaan unsur tokoh yang tertinggi di antara penguasaan unsur yang lain.

Belum memadainya kemampuan siswa kelas V SDN 26 dan SDN 28 tentunya dipengaruhi oleh beberapa faktor. Selain faktor internal, faktor eksternal juga mempengaruhi. Dalam kegiatan menulis kembali, selain mengandalkan kompetensi menulis, siswa juga harus menguasai kompotensi membaca yang juga diikuti oleh kompetensi menyimak dan berbicara. Penguasaan keempat kompetensi tersebut juga merupakan salah satu faktor pendukung dalam meningkatkan kemampuan menulis kembali cerita yang dibaca.

Berdasarkan pengamatan peneliti, faktor internal dan faktor ekternal mempengaruhi kemampuan siswa menulis kembali cerita rakyat yang dibaca. Faktorfaktor yang dapat menjadi penyebab rendahnya kemampuan siswa dalam menulis kembali cerita yang dibaca adalah sebagai berikut.

\subsection{Ditinjau dari siswa}

Siswa adalah individu yang mempunyai peranan penting dalam peningkatan kemampuan menulis kembali cerita yang dibaca. Dalam hal ini siswa masih mempunyai minat yang kurang terhadap membaca sehingga belum mampu mengambil pokok-pokok atau gagasan dari apa yang dibaca. Selain itu, kurangnya minat membaca membuat 
siswa masih merasa asing dengan cerita rakyat Aceh yang diberikan. Kemudian, selain membaca, siswa juga masih kesulitan dalam menulis. Kurangnya pengetahuan akan materi dan juga kurangya kosakata yang dikuasai siswa memjadikan siswa kebingungan atau kesulitan dalam memulai hal yang ingin ditulis. Di samping itu, motivasi siswa dalam membaca dan menulis juga masih kurang.

\subsection{Ditinjau dari pengajar}

Pengajar bahasa Indonesia jarang memberikan tugas menulis kembali cerita yang dibaca kepada siswa sehingga siswa hanya pandai membaca, tetapi belum mampu menulis kembali atau menceritakan kembali cerita yang telah dibaca. Lazimnya, selama ini siswa diberikan tugas yang berpaku pada teks, baik itu menulis maupun membaca. Artinya siswa selalu menulis atau menceritakan sesuatu dengan masih melihat teks.

\section{SIMPULAN DAN SARAN}

Simpulan penelitian ini adalah bahwa kemampuan siswa kelas V SDN dalam Gugus 3 Kota Sabang menulis kembali cerita rakyat yang dibaca belum mencapai kriteria nilai yang ditentukan. Hanya 40\% dari 40 siswa kelas V SDN 26 Sabang yang mencapai nilai kriteria yang ditentukan atau mempunyai kemampuan memadai dalam menulis kembali cerita yang dibaca. Sementara itu, hanya 30\% siswa kelas V SDN 28 yang mempunyai kemampuan memadai dalam menulis kembali cerita yang dibaca. Artinya, rata-rata sebanyak 35\% siswa kelas V SDN 26 dan SDN 28 mempunyai kemampuan yang memadai dalam menulis kembali cerita rakyat yang dibaca, sedangkan sebanyak 65\% lainnya tidak mencapai nilai kriteria yang ditentukan. Skor terendah untuk kedua sekolah berada pada unsur alur, sedangkan skor tertinggi adalah pada unsur tokoh. Belum tercapainya kemampuan siswa kelas V SDN 26 dan SDN 28 Sabang menulis kembali cerita yang dibaca disebabkan oleh siswa sendiri dan pengajar bahasa Indonesia.

Berikut ini dikemukakan dua saran yang dapat digunakan untuk meningkatkan kemampuan siswa menulis kembali cerita rakyat yang dibaca. Pertama, sebagai guru diharapkan dapat memberikan tugas kepada siswa untuk mengasah kemampan menulis dan membaca siswa dan diungkapkan kembali dalam bentuk tulisan atau lisan serta memberikan motivasi sehingga siswa mempunyai minat untuk menulis dan membaca. Kedua, pelaksana pendidikan perlu menerapkan literasi di sekolah sehingga siswa mempuyai kosakata yang banyak akan bahasa yang akan memudahkan siswa dalam menulis maupun berbicara.

\section{DAFTAR PUSTAKA}

Ara, LK. 2008. Cerita Rakyat dari Aceh: Jakarta: Grasindo.

Arikunto, Suharsimi. 2012. Prosedur Penelitian Suatu Pendekatan Praktek. Jakarta: Rineka Cipta. 
LINGUA, Vol. 16, No. 2, September 2019

p ISSN: 1979 9411; e ISSN: 2442 238X

Http://lingua.soloclcs.org; Email: presslingua@gmail.com

Center of Language and Cultural Studies, Surakarta, Indonesia

Sari, Mustika; Harun, Mohd \& Fitriani, Sarah Siti. 2019. Kemampuan Siswa Kelas V SDN

dalam Gugus 3 Kota Sabang Menulis Kembali Cerita Rakyat uang Dibaca.

Lingua (2019), 16(2): 195-206. Http://doi.org/10.30957/lingua.v16i2.267.

Danandjaja, James. 1997. Folklor Indonesia Ilmu Gosip, Dongeng, dan lain-lain. Jakarta: Grafiti.

Hardjono, Sartinah. 1988. Prinsip-Prinsip Pengajaran Bahasa dan Sastra. Jakarta: Proyek Pengembangan Lembaga Pendidikan Tenaga Kependidikan Depdikbud Dirjen Dikti.

Harun, Mohd. 2012. Pengantar Sastra Aceh. Bandung: Citapustaka Media Perintis.

Ishak, Saidulkarnain. 2014. Cara Menulis Mudah. Jakarta: Gramedia. Online. (Http://Books.google.co.id diakses tanggal 12 Desember 2018).

Nurgiyantoro, Burhan. 2004. "Penilaian Pembelajaran Sastra". Jurnal Diksi Vol. 11, No.1. Online. (http:scholar.google.co.id diakses tangga 31 Desember 2018).

Nurgiyantoro, Burhan. 2005. Sastra Anak: Pengantar Pemahaman Dunia Anak. Yogyakarta: Gadjah Mada University Press.

Nurgiyantoro, Burhan. 2010. Penilaian Pengajaran Bahasa dan Sastra. Yogyakarta: BPEE.

Kemendikbud RI. 2014. Permendikbud Republik Indonesia No.104 Penilaian Hasil Belajar oleh Pendidik pada Pendidikan Dasar dan Pendidikan Menengah. Jakarta: Kemendikbud RI.

Supardi. 2016. "Pembelajaran Menulis Kembali Dongeng yang Telah Dibaca dengan Metode Konstruktivisme di MTS Al Muttaqin Buper Jayapura". Jurnal Lingua, Vol. 13, No.2.

Suparno dan Muhammad Yunus. 2009. Keterampilan Dasar Menulis. Jakarta: Universitas Terbuka.

Widyaningrum, Heny Kusuma. 2018. "Pembelajaran Menulis Teks Cerita Dongeng Berbasis Kearifan Lokal Pada Siswa Kelas IV". JPE (Jurnal Pendidikan Edutama) Vol.5 No. 2 (Error! Hyperlink reference not valid. diakses pada Desember 2018) 
LINGUA, Vol. 16, No. 2, September 2019

p ISSN: 1979 9411; e ISSN: 2442 238X

Http://lingua.soloclcs.org; Email: presslingua@gmail.com

Center of Language and Cultural Studies, Surakarta, Indonesia

Sari, Mustika; Harun, Mohd \& Fitriani, Sarah Siti. 2019. Kemampuan Siswa Kelas V SDN dalam Gugus 3 Kota Sabang Menulis Kembali Cerita Rakyat uang Dibaca.

Lingua (2019), 16(2): 195-206. Http://doi.org/10.30957/lingua.v16i2.267. 